\title{
Environmental Factors and Prevalence of Hookworm infection and Strongyloidiasis in Rural East Kalimantan, Indonesia
}

\author{
Blego Sedionoto ${ }^{1,2, *}$, Sueptrakool Wasessombat ${ }^{1}$, Chuchard Punsawad $^{3}$, Witthaya Anamnart ${ }^{4}$ \\ ${ }^{1}$ Doctoral Program in Biomedical Sciences, School of Allied Health Sciences, Walailak University, Thasala. 80160, Thailand. \\ ${ }^{2}$ Department of Environmental Health, Faculty of Public Health Mulawarman University, Samarinda, 75123, Indonesia \\ ${ }^{3}$ Department of Parasitology, School of Medicine, Walailak University, Thasala 80160, Thailand. \\ ${ }^{4}$ Department of Environmental Health, School of Public Health, Walailak University, Thasala, 80160, Thailand
}

\begin{abstract}
The prevalence of hookworm infection and strongyloidiasis is serious public health concern globally. In rural East Kalimantan, Indonesia has high-risk environmental factors of the prevalence of hookworm infection and strongyloidiasis. In this study would show the infection rates, correlation analysis between environmental risk factors and prevalence of hookworm infection with statistical analysis. We performed a cross-sectional study among 213 participants from rural community of East Kalimantan Province, Indonesia. In this study used two diagnostic methods: Kato Katz and Koga agar plate culture/KAP culture for diagnosing of hookworm and Strongyloides infections. Chi-square analysis was used for study correlation between environmental factors and hookworm infection. Hookworm, strongyloides, and ascaris infections were found in this study; $44.1 \%, 16.4 \%$, and $7.5 \%$ respectively. Environmental risk factors such as; rainy season, quality of soil and infection hookworm and strongyloides in pet have significant correlation ( $\mathrm{p}$-value $<0.05$ ) with hookworm infection and strongyloidiasis. The prevalence of hookworm infection and strongyloidiasis has correlation with environmental factors, and the finding in this research could be contributed to decreasing program of hookworm infection and strongyloidiasis especially in rural community area.
\end{abstract}

Keywords: Environmental factors; hookworm infection; strongyloidiasis; rural East Kalimantan.

\section{Introduction}

The prevalence of hookworm infection and strongyloidiasis is serious public health concern globally. Hookworm infection and strongyloidiasis are prevalent in poor rural communities tropical and subtropical areas in many developing countries [1]. They are transmitted through in protected contact with soil are endemic in tropical and temperate regions. The prevalence of hookworm infection and strongyloidiasis was estimated in 2010 that 438.9 million people were infected with hookworm and 100 million with strongyloides. Almost $70 \%$ of these infections occur in Asia. [2,3].

Hookworm infection and strongyloidiasis are transmitted through in protected contact with soil are endemic in tropical and temperate regions. Human acquires the hookworm infection and strongyloidiasis through direct skin contact with infective third-stage larvae where the soil was contaminated by human feces penetrate the intact human skin and eventually reach small intestine [4].

Generally, hookworm infection and strongyloidiasis are found among poor people with poor environmental sanitation and where the climate is warm and humid [5,6]. Factors affecting difference in distribution of hookworm infection and strongyloidiasis may include good hygiene practices among population, availability of sewerage system and the length of rainy season. Environmental factors have contributed for transmission of diseases as well as growth and development of the worms $[7,8]$.

Environmental factors especially long rainy season may affect the decrease in prevalence of strongyloidiasis but not for hookworm infection. Prevalence of strongyloidiasis in south Thailand is lower than other parts of the country, in contrast, prevalence of hookworm infection is still high in the south. It is possible because of the failure in the control of hookworm infection due to 10 months-long rainy season in southern Thailand contrasted with 4 months-long rainy season in other parts [9]. The study in Cambodia reported the lower prevalence of strongyloidiasis in area with heavy rainfall than in low rainfall area. Moreover, high amount of soil organic carbon content affects the lower prevalence of strongyloidiasis [10]. Epidemiology study of hookworm infection and strongyloidiasis in Southern Laos showed $56.1 \%$ and $41 \%$ respectively where were heavy rainfall and poor sanitation. In this study, Baerman and Kato-Katz techniques were used for detecting them [11].

\footnotetext{
* Corresponding author: blego_kesling@yahoo.com
} 
In rural East Kalimantan province, Indonesia has environmental risk factors of prevalence of hookworm infection and strongyloidiasis that important to exploration association both of them. We perform a cross-sectional study in rural community in Muarakiaman and Marangkayu district to analysis of geography, texture of soil, humidity, hookworm, and strongyloides in pet, vegetation, elevation, volume rain, amount days of rain yearly, temperature and quality of soil as clay content, organic carbon of soil and $\mathrm{pH}$ of soil then was correlated with prevalence of hookworm infection and strongyloidiasis.

\section{Materials and Methods}

\subsection{Ethical consideration}

Official permission and ethical clearance for collection human fecal samples were obtained from headmaster and teacher. The study protocol was approved by the ethical clearance committee on human rights related to research involving human subjects, Walailak University HE: number WUEc-18-034-01.

Study Setting and Population

The study was carried out in rural area of Muarakaman district and Marangkayu district East Kalimantan province Indonesia. This research is a community based, was conducted during July 2018January 2019. Total of number participant is 213 participant who was joined and sent stool samples.

Field Procedures

For collecting stool samples, the first day was requested to head of household and member of household for requesting stool sample, second day in the morning would start to collect stool samples, were brought to parasitology laboratory Mulawarman University for diagnosis samples. Anothers day was done observation environmental conditions houses surrounding village.

\subsection{Laboratory Procedures}

Agar plate culture and Kato Katz technique Agar plate culture will be done as described by Koga et al., 1991 [12]. Briefly, a few grams of stool will be placed at the center of nutrient agar and kept at room temperature for five days. Tracks from larva crawling and larvae or adult worms will be observed. If positive, $10 \mathrm{ml}$ of $10 \%$ formalin will be added to agar surface for 5-10 minutes and transferred to centrifuged tube. Centrifugation at $2,500 \mathrm{rpm}$ for 5 minutes and supernatant will be discarded. The sediment will be examined for hookworm larvae and S. stercoralis larvae or adult worm.

For Kato-katz thick smear, $50 \mathrm{mg}$ of stool will be placed on slide and covered with a cellophane paper soaked in glycerin solution for 24 hours. The stool will be spread out using rubber stick. After 30 minutes will be examined and counted for eggs.[13]

\subsection{Environmental data}

Environmental data were collected consist such as vegetation, elevation of soil, kind of pets, kind of soil around houses, length of rainy season, humidity and temperature per year. Quality of soil as organic carbon content, clay content and $\mathrm{pH}$ were diagnosed by soil laboratory Mulawarman University. Vegetation and kind of soil around houses will be collected by observation form, kind of pet will be collected by questioner and observation, and length of rainy season, humidity and temperature per year will be collected from Central Bureau of Statistics (https://www.bps.go.id) and Central Bureau of meteorology, climatology, and Geophysical of Indonesia (https://www.bmkg.go.id).

\section{Data Analysis}

The prevalence of hookworm and Strongyloides infections was stratified according to environmental data and reported by descriptive statistic. Statistical analysis was performed by Chi-square and regression using SPSS verse 20 . The correlation analysis chi-square to evaluate association of hookworm and strongyloides infections with environmental risk factors and the level of significance was considered as $\mathrm{P}<0.05$.

\section{Results and Discussion}

\subsection{Study Sample}

A total of 213 individuals participated in this study. The age ranged between 2 and 70 years from 28 villages, with detail 12 villages from Muarakaman district and 16 villages from Marangkayu district, East Kalimantan Province Indonesia.

\subsection{Parasitological Findings}

Prevalence hookworm and strongyloides infections were diagnosed by Kato Katz technique and APC method showed of 213 tested samples from community have 94 $(44.1 \%)$ cases found positive with hookworm infection and $35(16.4 \%)$ cases found positive with strongyloides infection and addition finding of Ascaris lumbricoides as $16(7.5 \%)$. Detail data of prevalence of hookworm and strongyloides infections were explained below

Table 1. Prevalence of Hookworm infection and strongyloidiasis detected by Kato Katz among rural communities (213)

\begin{tabular}{|l|c|c|}
\hline \multirow{2}{*}{ Infection } & \multicolumn{2}{|l|}{$\begin{array}{l}\text { Hookworm and strongyloidiasis-Kato } \\
\text { Katz }\end{array}$} \\
\cline { 2 - 3 } & Positive & Negative \\
\hline Hookworm & $50(23.5 \%)$ & $163(78.5 \%)$ \\
\hline Strongyloides & 0 & $213(100 \%)$ \\
\hline $\begin{array}{l}\text { Ascaris } \\
\text { lumbricoides }\end{array}$ & $16(7.5 \%)$ & $197(92.5 \%)$ \\
\hline
\end{tabular}

Result of diagnosis of hookworm infection was showed 50 cases $(23.5 \%)$ and the finding of hookworm 
increased by APC method as 94(44.1\%). Prevalence of strongyloides infection was not found, but APC method could find stronyloides infection as 35(16.4\%).

Table 2. Prevalence of Hookworm infection and strongyloidiasis detected by APC among rural communities (213)

\begin{tabular}{|l|c|c|}
\hline \multirow{2}{*}{ Infection } & \multicolumn{2}{|l|}{$\begin{array}{l}\text { Hookworm and strongyloidiasis- } \\
\text { APC }\end{array}$} \\
\cline { 2 - 3 } & Positive & Negative \\
\hline Hookworm & $94(44.1 \%)$ & $119(55.9 \%)$ \\
\hline Strongyloides & $35(16.4 \%)$ & $179(83.6 \%)$ \\
\hline
\end{tabular}

\subsection{Sensitivity of diagnostic method for hookworm and strongyloides infections}

By KAP culture technique showed 94(44.1\%) of prevalence of hookworm infection and 35(16.4\%) of prevalence of strongyloidiasis, KAP culture method is higher of sensitivity than Kato-Katz technique on diagnosis of hookworm infection and strongyloides in community of Muarakaman dan Marangkayu districts East Kalimantan province.

Table 3. Sensitivity of diagnostic method for hookworm infection and strongyloidiasis

\begin{tabular}{|l|c|c|}
\hline \multirow{2}{*}{ Infection } & \multicolumn{2}{|c|}{ Diagnostic technique } \\
\cline { 2 - 3 } & $\begin{array}{c}\text { Kato-Katz tick } \\
\text { smear }\end{array}$ & $\begin{array}{c}\text { Koga agar plate } \\
\text { culture }\end{array}$ \\
\hline Hookworm & $50(23.5 \%)$ & $94(44.1 \%)$ \\
\hline S. stercoralis & 0 & $35(16.4 \%)$ \\
\hline
\end{tabular}

As far as we know, the most sensitive method for S. stercoralis diagnosis is KAP culture [14]. We used Kato-Katz tick smear and KAP culture on double stool sample from community, in total found $23.5 \%$ infected of hookworm infection and $0 \%$ infected of strongyloidiasis diagnosed by Kato Katz and incresing . KAP culture has sensitivity more than Kato Katz in this research with founding of prevalence hookworm and strongyloides, $44.1 \%$ and $16.4 \%$ respectively. This technique can explain detail of growing up each step development of filariform larvae particularly for detecting of filariform larvae of S. stercoralis. Quoted by Steinmann P et al (2007) [15], S. stercoralis was found only by Baermann technique and Koga agar plate method. In diagnosis S stercoralis larvae KAP culture is more sensitivity than Baermann technique quoted by Witthaya Anamnart et al 2015 [9].

\subsection{Environmental Factors and Hookworm infection and Strongyloidiasis}

Statistical analysis of hookworm and strongyloides infection between environmental factors such as geography, texture of soil, infection status of pet, humidity, vegetation, elevation, amount day of rain, volume of rain, temperature, $\mathrm{pH}$, clay content of soil, organic carbon of soil, explained detail below;

Table 4. Correlation Environmental Factors and Hookworm infection

\begin{tabular}{|c|c|c|c|}
\hline \multirow{2}{*}{$\begin{array}{c}\text { Environmental } \\
\text { Factors }\end{array}$} & \multicolumn{2}{|c|}{$\begin{array}{c}\text { Status of Diagnosis } \\
\text { Participants }\end{array}$} & \multirow{2}{*}{$\begin{array}{c}\text { P- } \\
\text { value }\end{array}$} \\
\hline & Positive & Negative & \\
\hline $\begin{array}{l}\text { Texture of soil } \\
\text { Loamy sand } \\
\text { Sandy clay loam } \\
\text { Silty clay } \\
\text { Sand } \\
\text { Clay }\end{array}$ & $\begin{array}{l}4(66.7 \%) \\
42(47.2 \%) \\
31(43.7 \%) \\
15(34.9 \%) \\
2(50 \%)\end{array}$ & $\begin{array}{l}2(33.3 \%) \\
47(52.8 \%) \\
40(56.3 \%) \\
28(65.1 \%) \\
2(50 \%)\end{array}$ & 0.537 \\
\hline $\begin{array}{l}\text { Hookworm in cat } \\
\text { Infected } \\
\text { hookworm in cat } \\
\text { Non-infected } \\
\text { hookworm in cat }\end{array}$ & $\begin{array}{l}94(44.3 \%) \\
1(100 \%)\end{array}$ & $\begin{array}{l}118(55.7 \%) \\
0(0 \%)\end{array}$ & 0.373 \\
\hline $\begin{array}{l}\text { Hookworm in dog } \\
\text { Infected } \\
\text { hookworm in dog } \\
\text { Non-infected } \\
\text { hookworm in dog }\end{array}$ & $\begin{array}{l}36(30.8 \%) \\
58(60.4 \%)\end{array}$ & $\begin{array}{l}81(69.2 \%) \\
38(39.6 \%)\end{array}$ & 0.000 \\
\hline $\begin{array}{l}\text { Humidity } \\
\text { Area } 1 \\
\text { Area } 2 \\
\end{array}$ & $\begin{array}{l}36(30.5 \%) \\
58(61.1 \%)\end{array}$ & $\begin{array}{l}81(69.5 \%) \\
37(39.1 \%)\end{array}$ & 0.000 \\
\hline $\begin{array}{l}\text { Vegetation } \\
\text { Palm plantation } \\
\text { Rubber plantation } \\
\text { Field rice/paddy } \\
\text { plantation } \\
\text { Palm and rubber } \\
\text { plantation } \\
\text { Banana/fruit } \\
\text { garden }\end{array}$ & $\begin{array}{l}79(55.2 \%) \\
6(17.6 \%) \\
3(16.3 \%) \\
1(20 \%) \\
5(38.5)\end{array}$ & $\begin{array}{l}64(44.8 \%) \\
28(82.4 \%) \\
15(83.3 \%) \\
4(80 \%) \\
8(61.5 \%)\end{array}$ & 0.000 \\
\hline $\begin{array}{l}\text { Geography of } \\
\text { village areas } \\
\text { Buffer } \\
\text { sea/coastal area } \\
\text { Buffer of river } \\
\text { Hill }\end{array}$ & $\begin{array}{l}27(37.5 \%) \\
59(59.9 \%) \\
11(23.9 \%)\end{array}$ & $\begin{array}{l}45(62.5 \%) \\
39(41.1 \%) \\
35(76.1 \%)\end{array}$ & 0.000 \\
\hline $\begin{array}{l}\text { Quality of Soil } \\
\text { Organic Carbon in } \\
\text { Soil( } 10 \text { clusters) } \\
\text { Clay content }(12 \\
\text { cluster) } \\
\text { pH of soil (14 } \\
\text { cluster) }\end{array}$ & $\begin{array}{l}94(44.1 \%) \\
94(44.1 \%) \\
94(44.1 \%)\end{array}$ & $\begin{array}{l}119(55.9 \%) \\
119(55.9 \%) \\
119(55.9 \%)\end{array}$ & $\begin{array}{l}0.000 \\
0.000 \\
0.000\end{array}$ \\
\hline $\begin{array}{l}\text { Temperature } \\
\text { Area } 1 \\
\text { Area } 2 \\
\text { Area } 3 \\
\end{array}$ & $\begin{array}{l}36(30.5 \%) \\
10(83.3 \%) \\
48(57.8 \%) \\
\end{array}$ & $\begin{array}{l}82(69.5 \%) \\
2(16.7 \%) \\
35(42.2 \%) \\
\end{array}$ & 0.000 \\
\hline $\begin{array}{lr}\begin{array}{l}\text { Amount day } \\
\text { rain yearly }\end{array} \\
\begin{array}{l}\text { Station } \\
\text { days })\end{array} & 1(86.9 \\
\begin{array}{l}\text { Station } \\
\text { days })\end{array} & 2(109 \\
\end{array}$ & $\begin{array}{l}58(61.1 \%) \\
36(30.5 \%)\end{array}$ & $\begin{array}{l}37(38.9 \%) \\
82(69.5 \%)\end{array}$ & 0.000 \\
\hline $\begin{array}{l}\text { Volume of rain per } \\
\text { ten days } \\
\text { Station } 1\left(71 \mathrm{~mm}^{3}\right) \\
\text { Station } 2\left(95 \mathrm{~mm}^{3}\right)\end{array}$ & $\begin{array}{l}58(61.1 \%) \\
36(30.5 \%)\end{array}$ & $\begin{array}{l}37(38.9 \%) \\
82(69.5 \%)\end{array}$ & 0.000 \\
\hline $\begin{array}{lr}\begin{array}{l}\text { Elevation } \\
\text { above of }\end{array} \\
\text { surface }(\mathrm{m})\end{array}$ & $58(61.1 \%)$ & $37(38.9 \%)$ & 0.000 \\
\hline
\end{tabular}




\begin{tabular}{|l|l|l|l|}
\hline $\begin{array}{l}\text { Station 1 }(15 \mathrm{~m}) \\
\text { Station 2 }(32 \mathrm{~m})\end{array}$ & $36(30.5 \%)$ & $82(69.5 \%)$ & \\
\hline
\end{tabular}

Result of statistical analysis showed that environmental factors majority have association with prevalence of hookworm infection, the environmental factors, including geography of area, hookworm in dog, humidity, vegetation, elevation. amount day of rain yearly, volume of rain and quality of soil as organic carbon of soil, clay content of soil and $\mathrm{pH}$ of soil have significance $\quad(\mathrm{P}$-value $<0.05)$ with prevalence of hookworm infection in East Kalimantan community. But texture of soil and hookworm in cat have not significance $(\mathrm{P}$-value $>0.05)$ with prevalence of hookworm infection.

Table 5. Correlation Environmental Factors and Strongyloidiasis

\begin{tabular}{|c|c|c|c|}
\hline \multirow{2}{*}{$\begin{array}{c}\text { Environmental } \\
\text { Factors }\end{array}$} & \multicolumn{2}{|c|}{$\begin{array}{l}\text { Status of Diagnosis } \\
\text { Participants }\end{array}$} & \multirow{2}{*}{$\begin{array}{c}P \text { - } \\
\text { value }\end{array}$} \\
\hline & Positive & Negative & \\
\hline $\begin{array}{l}\text { Texture of soil } \\
\text { Loamy sand } \\
\text { Sandy clay loam } \\
\text { Silty clay } \\
\text { Sand } \\
\text { Clay }\end{array}$ & $\begin{array}{l}0(100 \%) \\
14(15.7 \%) \\
6(8.5 \%) \\
13(30.2 \%) \\
2(50 \%)\end{array}$ & $\begin{array}{l}6(100 \%) \\
75(84.3 \%) \\
65(43.7 \%) \\
30(91.5 \%) \\
2(50 \%)\end{array}$ & 0.008 \\
\hline $\begin{array}{l}\text { Strongyloides in } \\
\text { cat } \\
\text { Infected } \\
\text { Strongyloides in } \\
\text { cat } \\
\text { Non infected } \\
\text { Strongyloides in } \\
\text { cat }\end{array}$ & $\begin{array}{l}23(16.1 \%) \\
12(17.1 \%)\end{array}$ & $\begin{array}{l}120(83.9 \%) \\
58(82.9 \%)\end{array}$ & 0.845 \\
\hline $\begin{array}{l}\text { Strongyloides in } \\
\text { dog } \\
\text { Infected } \\
\text { Strongyloides in } \\
\text { dog } \\
\text { Non infected } \\
\text { Strongyloides in } \\
\text { dog } \\
\end{array}$ & $\begin{array}{l}17(28.3 \%) \\
18(11.8 \%)\end{array}$ & $\begin{array}{l}43(71.7 \%) \\
135(88.2 \%)\end{array}$ & 0.003 \\
\hline $\begin{array}{l}\text { Humidity } \\
\text { Area } 1 \\
\text { Area } 2\end{array}$ & $\begin{array}{l}28(23.7 \%) \\
7(7.4 \%)\end{array}$ & $\begin{array}{l}90(76.3 \%) \\
88(92.6 \%)\end{array}$ & 0.001 \\
\hline $\begin{array}{l}\text { Vegetation } \\
\text { Palm plantation } \\
\text { Rubber plantation } \\
\text { Field rice/paddy } \\
\text { plantation } \\
\text { Palm and rubber } \\
\text { plantation } \\
\text { Banana/fruit } \\
\text { garden }\end{array}$ & $\begin{array}{l}24(16.8 \%) \\
6(17.6 \%) \\
3(16.7 \%) \\
1(20 \%) \\
1(7.7 \%)\end{array}$ & $\begin{array}{l}119(83.2 \%) \\
28(82.4 \%) \\
15(83.3 \%) \\
4(80 \%) \\
12(92.3 \%)\end{array}$ & 0.936 \\
\hline $\begin{array}{l}\text { Geography of } \\
\text { village areas } \\
\text { Buffer } \\
\text { sea/coastal area } \\
\text { Buffer of river } \\
\text { Hill }\end{array}$ & $\begin{array}{l}19(26.4 \%) \\
9(9.5 \%) \\
7(15.2 \%)\end{array}$ & $\begin{array}{l}53(73.6 \%) \\
86(80.5 \%) \\
39(84.8 \%)\end{array}$ & 0.014 \\
\hline $\begin{array}{ll}\text { Geography } & \text { of } \\
\text { village areas } & \\
\text { Buffer } & \text { of } \\
\text { sea/coastal area } & \end{array}$ & $\begin{array}{l}27(37.5 \%) \\
59(59.9 \%) \\
11(23.9 \%)\end{array}$ & $\begin{array}{l}45(62.5 \%) \\
39(41.1 \%) \\
35(76.1 \%)\end{array}$ & 0.000 \\
\hline
\end{tabular}

\begin{tabular}{|c|c|c|c|}
\hline $\begin{array}{l}\text { Buffer of river } \\
\text { Hill }\end{array}$ & & & \\
\hline $\begin{array}{l}\text { Quality of Soil } \\
\text { Organic Carbon in } \\
\text { Soil(10 clusters) } \\
\text { Clay content (12 } \\
\text { cluster) } \\
\text { pH of soil (14 } \\
\text { cluster) }\end{array}$ & $\begin{array}{l}35(16.4 \%) \\
35(16.4 \%) \\
35(16.4 \%)\end{array}$ & $\begin{array}{l}178(83.6 \%) \\
178(83.6 \%) \\
178(83.6 \%)\end{array}$ & $\begin{array}{l}0.01 \\
0.01 \\
0.01\end{array}$ \\
\hline $\begin{array}{l}\text { Temperature } \\
\text { Area } 1 \\
\text { Area } 2 \\
\text { Area } 3 \\
\end{array}$ & $\begin{array}{l}28(23.7 \%) \\
1(8.3 \%) \\
6(7.2 \%) \\
\end{array}$ & $\begin{array}{l}90(76.3 \%) \\
11(91.7 \%) \\
77(92.8 \%)\end{array}$ & 0.006 \\
\hline $\begin{array}{lr}\begin{array}{l}\text { Amount day } \\
\text { rain yearly }\end{array} \\
\begin{array}{l}\text { Station } \\
\text { days) }\end{array} & 1(86.9 \\
\begin{array}{l}\text { Station } \\
\text { days) }\end{array} & 2(109 \\
\end{array}$ & $\begin{array}{l}7(7.4 \%) \\
28(23.7 \%)\end{array}$ & $\begin{array}{l}88(92.6 \%) \\
90(76.3 \%)\end{array}$ & 0.001 \\
\hline $\begin{array}{l}\text { Volume of rain per } \\
\text { ten days } \\
\text { Station } 1\left(71 \mathrm{~mm}^{3}\right) \\
\text { Station } 2\left(95 \mathrm{~mm}^{3}\right)\end{array}$ & $\begin{array}{l}7(7.4 \%) \\
28(23.7 \%)\end{array}$ & $\begin{array}{l}88(92.6 \%) \\
90(76.3 \%)\end{array}$ & 0.001 \\
\hline $\begin{array}{l}\text { Elevation from } \\
\text { above of sea } \\
\text { surface }(\mathrm{m}) \\
\text { Station } 1(15 \mathrm{~m}) \\
\text { Station } 2(32 \mathrm{~m})\end{array}$ & $\begin{array}{l}28(23.7 \%) \\
7(7.4 \%)\end{array}$ & $\begin{array}{l}90(76.3 \%) \\
88(92.6 \%)\end{array}$ & 0.001 \\
\hline
\end{tabular}

Result of statistical analysis showed that environmental factors majority have association with prevalence of strongyloidiasis, the environmental factors, including geography of area, strongyloides in dog, humidity, elevation. amount day of rain yearly, volume of rain and quality of soil as organic carbon of soil, clay content of soil and $\mathrm{pH}$ of soil have significance $(\mathrm{P}$-value $<0.05)$ with prevalence of strongyloides infection in East Kalimantan community. But texture of soil, vegetation and strongyloides in cat have not significance $(\mathrm{P}$-value $>0.05)$ with prevalence of strongyloides infection in community.

Hookworm infection and strongyloidiasis are both neglected tropical diseases [16]. In poor countries with tropical climate, condition favorable for transmission of these parasites have higher the prevalence of hookworm infection and strongyloidiasis [17]. Furthermore, low socioeconomic status and low hygiene living conditions of the rural population are strongly associated with hookworm infection and strongyloidiasis. In southeast Asia, recent work in Cambodia reported a very high infection rate of Takeo Province [10]. In Indonesia, especially in East Kalimantan, there have been few studies on both of hookworm infection and strongyloidiasis.

Environmental factors of hookworm and strongyloidiasis in East Kalimantan has similar to south Thailand including long rainy season, temperature and several geography areas, then the prevalence of hookworm infection in East Kalimantan Province $(44.1 \%)$ is higher than in south Thailand but equal for Strongyloidiasis, that condition was caused other environmental risk factors like quality of soil such as organic carbon of soil, clay content and $\mathrm{pH}$. [9]. 
Prevalence hookworm infection in East Kalimantan has similar to study in southern Laos and Cambodia where hookworm still high but more than prevalence of strongyloidiasisa. The study in Cambodia reported the lower prevalence of strongyloidiasis in area with heavy rainfall than in low rainfall area. Moreover, high amount of soil organic carbon content affects the lower prevalence of strongyloidiasis [10]. Epidemiology study of hookworm infection and strongyloidiasis in Southern Laos showed $56.1 \%$ and $41 \%$ respectively where were heavy rainfall and poor sanitation. In this study, Baerman and Kato-Katz techniques were used for detecting them [11].

Environmental factors of hookworm infection and strongyloidiasis in East Kalimantan have significance with high of prevalence hookworm infection and strongyloidiasis such as geography, vegetation, humidity, volume and amount day of rain organic carbon of soil and clay content of soil, the environmental factors make survive of infective larvae of hookworm and strongyloides, had explained with Gracia (2007) [18] that a significant increase in the prevalence of hookworm infection and strongyloides with environmental conditions. Changing environmental conditions, specifically deforestation and subsequent silting of local river, have caused periodic flooding with deposition on layer of sandy loam topsoil increased soil moisture. These conditions, all of which are conducive to hookworm transmission, have allowed hookworm to reemerge as an important human pathogen in this area. This example emphasizes the value of longitudinal surveillance data for monitoring disease prevalence. Shifts in the prevalence of infectious disease can be caused by environmental changes, including planned human activity, or can be an indirect consequence of political strife, and these factors should always be considered when changes in infections disease patterns are detected.

\section{Conclusion}

The prevalence of hookworm and Strongyloides infections among community in rural East Kalimantan has correlation with environmental factors. Result of the study analysis can make strong contribution to preventing program by ecological root. Preventing program of reduction prevalence hookworm and strongyloides infections by treatment of environmental risk factors is effective program for decreasing hookworm and strongyloides infections in community area.

We are grateful to the Muarakaman district and Marangkayu district communities and local authorities of East Kalimantan province. We deeply thank the Dean of Faculty of Public Health Mulawarman University for giving us permission to use the laboratory. This work was supported by Walailak University grant (contract no 17/2561).

\section{References}

1. Wardell R, Clements ACA, Lal A, Summers D, Llewellyn S, Campbell SJ, et al., An environmental assessment and risk map of Ascaris lumbricoides and Necator americanus distributions in Manufahi District, Timor-Leste. PLoS Negl Trop Dis 11, 5 (2017)

2. World Health Organization, Helminth Control In School-Age Children: A Guide For Managers of Control Program. 2nd ed. Geneva: World Health Organization (2011)

3. Bethony J, Brooker S, Albonico M, Geiger SM, Loukas A, Diemert D \& Hotez PJ, Soil-Transmitted Helminth Infections: Ascariasis, Trichuriasis, and Hookworm. Lancet 367, 1521-1532 (2006).

4. Armelle Forrer, Virak Khieu, Christian Schindler, Fabian Schär, Hanspeter Marti, Meng Chuor Char, et al., Ivermectin Treatment and Sanitation Effectively Reduce Strongyloides stercoralis Infection Risk in Rural Communities in Cambodia, PLoS Negl Trop Dis 10,8: 1-17 (2016).

5. Bannon JP, Fater M \& Solit R, Intestinal Ileus Secondary to Strongyloides stercoralis Infection: Case Report and Review of The Literature. Am Surg 61, 377-380 (1995).

6. Hall A, Conway DJ, Anwar KS \& Rahman ML, Strongyloides stercoralis in an Urban Slum Community in Bangladesh: Factors Independently Associated with Infection. Trans R Soc Trop Med Hyg 88, 527-530 (1994).

7. Anamnart W. Pattanawongsa, A. Maleewong, P. Intapan., Morakote N, Janwan., P. Maleewong., W., Detrimental Effect of Water Submersion of Stools on Development of Strongyloides stercoralis, PLOS ONE 8, e82339 (2013)..

8. Prasit Na-Ek, Oranuch Sanpool, Jurairat Jongthawin, Witthaya Anamnart, Pewpan M. Intapan Pennapa Chamavit, Wanchai Maleewong, Restoration of Hookworm Egg Development After Prolonged Storage in Stool Suspension, Parasitol Res 115, 2817-2823 (2016).

9. Anamnart, Pewpan Maleewong Intapan, Attarat Pattanawongsa, Pennapa Chamavit, Supreecha Kaewsawat, Wanchai Maleewong, Effect of Dilution of Stool Soluble Component on Growth and Development of Strongyloides Sci, Rep. 5, 10749: 1-5 (2015).

10. Khieu V, schar f, forrer a, hattendorf, marti, duong $\mathrm{s}$, vounatsou $\mathrm{p}$, muth $\mathrm{s}$, odermatt $\mathrm{p}$, High prevalence and special distribution of strongyloides stercoralis in rural Cambodia. PloS Negl Trop Dis 2014,; 8 e2854

11. Youthanavanh Vonghachack, Somphou Sayasone, Dalouny Bouakhasith, Keoka Taisayavong, Kongsap Akkavong, Peter Odermatt, Epidemiology of Strongyloides stercoralis on Mekong Islands in Southern Laos, Acta Tropica 141, 289-294 (2015)

12. Koga K, Kasuya S, Khamboonruang C, Sukhavat $\mathrm{K}$, Ieda M, Takatsuka N, Kita K \& Ohtomo H, $A$ Modified Agar Plate Method for Detection of 
Strongyloides stercoralis, Am J Trop Med Hyg 45, 518-521 (1991).

13. Katz N, Chaves A \& Pellegrino J, A Simple Device for Quantitative Stool Thick-Smear Technique in Schistosomiasis mansoni, Rev Inst Med Trop Sao Paulo 14, 397-400 (1972).

14. Peter Steinmann, Peiling Yap, Jürg Utzinger, ZunWei Du, Jin-Yong Jiang et al., Control of soiltransmitted helminthiasis in Yunnan province, People's Republic of China: Experiences and lessons from a 5-year multi-intervention trial, Acta Tropica 141, 271-280 (2015).

15. Steinmann P, Zhou XN, Du ZW, Jiang JY, Wang LB, Wang XZ, Li LH, Marti H \& Utzinger J., Occurrence of Strongyloides stercoralis in Yunnan Province, China, and comparison of diagnostic methods, PLoS Negl Trop Dis 1, e75 (2007).

16. Anamnart, W. Pattanawongsa A. Intapan P. M. and Maleewong W., Albendazole Stimulates the Excretion of Strongyloides Stercoralis Larvae in Stool Specimens and Enhances Sensitivity for Diagnosis of Strongyloidiasis, Journal of Clinical Microbiology, 48, 4216-4220 (2010).

17. Jongwutiwes S., Charoenkom M., Sitthichareonchai P., Akaraborvorn P., Putaportip, C., Increased sensitifity of routine laboratory detection of strongyides stercoralis and hookworm by agar-plate culture, Trans r soc trop med hyg, 93: 398-400 (1999)

18. Garcia, Lynne Shore, Diagnostic Medical Parasitology, ASM Press Washington D.C Fifth Edition Chapter 10, 266-270 (2007). 